\title{
Article \\ Perpetrators, Presidents, and Profiteers: Teaching Genocide Prevention and Response through Classroom Simulation
}

\author{
Waitman Wade Beorn \\ Virginia Holocaust Museum, Richmond, VA 23223, USA; E-Mail: wbeorn@vaholocaust.org
}

Submitted: 26 May 2015 | In Revised Form: 16 July 2015 | Accepted: 22 July 2015 |

Published: 26 November 2015

\begin{abstract}
Perhaps the most difficult aspect of genocide studies to impart to students is that of genocide prevention and response. However, without a critical understanding of these issues, our future leaders and policy makers may be at a disadvantage when faced with very real genocides. This article explores the benefits and challenges of teaching this topic through classroom simulation at the university level by discussing in-depth one simulation created and used by the author.
\end{abstract}

\section{Keywords}

education; genocide; prevention; response; R2P

\section{Issue}

This article is part of the special issue "Mass Atrocity Prevention", edited by Professor Karen E. Smith (London School of Economics and Political Science, UK).

(C) 2015 by the author; licensee Cogitatio (Lisbon, Portugal). This article is licensed under a Creative Commons Attribution 4.0 International License (CC BY).

\section{Introduction}

In December 2014, a United Nations helicopter was shot down near the town of Walikale in the North Kivu province of the Democratic Republic of Congo. Thirtythree United Nations peacekeepers were killed. The UN issued the following statement: "We are deeply saddened by the death of 33 UN troops that were killed in DRC. Their efforts towards peace will not be in vain. We condemn the actions of whoever shot the helicopter down. We also demand they step forward and accept responsibility for their actions. We are currently investigating the situation. The UN is committed to the peace of the region" (Hilsum, 2014) ${ }^{1}$. The situation remained unclear but it was rumored that the missiles used had been supplied by China. Meanwhile, a violent split occurred between two powerful rebel militia groups operating in the region. General Nkende, who has close ties with DRC President Joseph Kabila, ap-

1 This is a fictional blog entry written by a student playing a freelance reporter in the class. peared to have lost control of a mysterious fellow rebel leader known as the Panther of Kalehe. Though he denied it, Nkende appeared to have issued orders for the Panther to begin an ethnic cleansing of Hutu civilians in the Kivu provinces. CNN reported that this recent outbreak of violence led to at least 10,000 deaths and that "The ICRC is overwhelmed trying to provide aid." (Gladstone, 2014). ${ }^{2}$ Despite the recent defeat of M-23 in the Kivu provinces that ethnic and political violence flared again with deadly results including entire villages murdered by forces under the control of General Nkende and the Panther of Kalehe. The resulting refugee crisis displaced thousands more, destabilized the eastern provinces, and exacerbated powerful conflicts between Uganda and Rwanda and the Democratic Republic of Congo. ${ }^{3}$

Fortunately, none of these events actually took

\footnotetext{
${ }^{2}$ This is a fictional article written by a student in the class.

${ }^{3}$ All of the fictional events in this scenario were developed by students in HIST 4740: Comparative Genocide at the University of Nebraska-Omaha.
} 
place but were generated in the course of a four week Genocide Prevention and Response Exercise (GENPREVEX) which took place in the context of my course on Comparative Genocide at the University of NebraskaOmaha. This multi-faceted exercise included seeking to define a genocide, to determine the motivations of the perpetrators, and to illustrate the challenges in orchestrating a response. In this article, I will explore the difficult challenges of educating students at the university level not only on genocide but also on its prevention and the responses to it. As part of this contextualization, I will focus on the GENPREVEX that I used in the course, describing its methodology and the advantages as well as challenges of the exercise. This discussion addresses the benefits, difficulties, and considerations associated with using a simulation pedagogy at the university level to teach about responses to genocide in the modern context.

\section{Teaching about Genocide in the University Classroom}

Genocide is a study that often forces students and adults to make a "leap in their imagination" because "their vocabulary of morality fails them and their vision of a normal world is forced to expand to take in the most divergent visual and written images." - Strom, Margot Stem, and William S. Parsons, Facing History and Ourselves: Holocaust and Human Behavior. (Parsons \& Totten, 1991, p. 86)

Genocide education in the university classroom continues to be seen in the context of Holocaust education because the Holocaust was the first genocide to receive real attention at both the secondary and higher educational levels. Even the teaching of this important topic received relatively little attention until the 1970s when a combination of public interest and the rise of Holocaust denial spurred a push, led in large part by survivors, to include the Holocaust in educational curricula. The goal in doing so was to combat both benign ignorance and outright denial. Looking back after forty years, it is not perhaps not surprising that, for some, "the Holocaust became the hegemonic model of genocide." (Apsel, 2004, p. 109) Battles over the uniqueness of the Holocaust have contaminated both the study of this period and of the larger topic of genocide. For many, the Holocaust is seen as a singular and/or unexplainable event. It is also often, therefore, seen as without comparison, sometimes to the extent that any attempt at comparison is seen as disrespectful. Such a viewpoint places the Holocaust outside the realm (and hence discussion) of genocide in general. As a result, the "other genocides" fall by the wayside as they "do not have a critical mass (as the Holocaust does) that advocates for the inclusion of such information in the classroom"
(Totten, 2001a). ${ }^{4}$ Therefore, one must recognize that theoretical and philosophical approaches to understanding the Holocaust remain pivotal in our approach to "other" genocides and toward a comparative perspective.

As such, one of the challenges of teaching "other" genocides has sometimes been the artificial pressure to measure non-Holocaust atrocities in comparison with the Holocaust. ${ }^{5}$ Fortunately, more and more educators are teaching about genocide in its own right in formats in which the Holocaust is one genocide among many without need for an "Olympics of suffering" which attempts to privilege the pain of one victim group over another. We now see that both Holocaust and Genocide education can coexist without competing. This is evident most clearly at the university level in the proliferation of Holocaust and Genocide Studies centers, programs, and curricula. Indeed, the Holocaust can now be a helpful entrée into the field of comparative genocide. Teaching about genocide at the secondary level, however, lags far behind. Holocaust and Genocide scholar Samuel Totten sees the teaching of genocide as falling into what Elliot Eisner calls a "Null curriculum." Eisner defines this by saying "what schools do not teach may be as important as what they do teach....Ignorance is not simply a void [;] it has important effects on the kinds of options one is able to consider; the alternatives one can examine, and the perspectives with which one can view a situation or problem." (Totten, 2001a, p. 209) Thus, one might argue that a comprehensive study of genocide offers opportunities that a more narrowly focused course does not. This is not, of course, an attempt to advocate the removal or minimization of the Holocaust in our curricula but rather to argue for the addition of genocide studies as a natural partner for such courses and against the construction of an artificial boundary between the two. It is perhaps ironic (or perhaps fitting) that the word "genocide" first appeared in print in a book about the Holocaust-Rafael Lemkin's Axis Rule in Occupied Europe. Lemkin coined the term in 1944. Indeed though, it must be pointed out that Lemkin himself formulated the concept of genocide in the wake of the murder of Armenians during World War I rather than the Holocaust (Bartrop, 2012, p. 186; Schabas, 2009, p. 30).

So why teach about genocide? One answer is that "a fundamental reason for studying genocide is to provide students with information and learning opportunities that will help them examine questions of human behavior" (Parsons \& Totten, 1991, p. 86). That is to say, the all-encompassing nature of genocide provides opportunities for students to explore complexities that

\footnotetext{
${ }^{4}$ Here, "other genocides" is used by some as a linguistic minimization when compared to the Holocaust.

${ }^{5}$ Even the term "other genocides" perhaps mistakenly imparts a uniqueness to the Holocaust.
} 
continue to exist in the world around them and to compare how varying circumstances and individuals in different times and for different reasons resulted in the mass killing of innocent human beings. Indeed, it is in the comparison that students often find the most intellectual growth. A second pressing motivation for teaching about genocide as its prevention is that genocides, sadly, remain frequent occurrences in modern life. The study of the Holocaust may inspire students to become socially active against discrimination and violence in the world, but, given their focus on more recent mass atrocities, courses in genocide studies more often demand that students "not only to learn about the complex processes of history and human destructiveness but also to act, to intervene, and to become engaged in constructive human actions" (Apsel, 2004, p. 120). Indeed, including the prevention aspect in such courses seeks to "develop our sense of the ongoing challenges of being part of an engaged, committed citizenry" (Apsel, 2004, p. 124). Calls for actions about today's potential genocides and mass atrocities accompany teaching about genocide almost explicitly and these calls must go beyond the platitude of "raising awareness." We are challenged to ask how we will respond and prevent these tragedies in a way that Holocaust education does not always overtly demand. Fortunately, more and more, the Holocaust can be seen as "entry point to a "multidirectional memory'" that does not exclude comparison or discussion of other genocides (Bos, 2014, p. 417). Current events throughout the world reinforce the fact that leaders who can recognize, prevent, and/or respond to genocides will continue to be vital players in the protection of human rights around the globe.

\section{HIST 4740: Comparative Genocide}

"Teachers need to send a clear message to students that studying complex human behavior usually defies simple answers." - William Parsons and Samuel Totten (Parsons \& Totten, 1991, p. 87)

Designing a course in comparative genocide can be a daunting prospect. First, it must be noted that this article is based on a U.S. university level course. Time available, accessibility, and other teaching requirements will vary at different educational levels and in different countries. Thus, the discussion of the course and the GENPREVEX should be seen as one approach that can be modified to suit different student audiences. Creating an effective comparative genocide course by its very nature entails mastery in several different content areas. First, students must struggle with the very definition of what genocide is and the historical development of the term. Second, they must also understand the nuances of human psychology as it relates to perpetrators, victims, and bystanders. Third, they must be conversant in the complexities of multiple genocides. Lastly, they must begin to tackle the immensely difficult issues of genocide prevention, the responsibility to protect, responses to genocide, and various forms of post-genocide justice. These admittedly lofty goals motivated my development of HIST 4740: Comparative Genocide at the University of Nebraska-Omaha.

The course relied on Ben Kiernan's monumental Blood and Soil as the foundational text in addition to three other assigned texts (see footnote). ${ }^{6}$ We began with a discussion and debate about how to define genocide. Thus, from the very beginning, complexity formed a main theme of the course. Our next series of lessons focused on the psychology of genocide beginning with Milgram and Zimbardo and discussing recent scholarship on why people kill (Milgram, 1969; Staub, 1989; Waller, 2002; Zimbardo, Musen, \& Polito, 1992). We then moved on to our first genocide, that of the Native Americans in the United States (Lindsay, 2012). Each four-lesson block covering a particular genocide started with a general introduction from Kiernan's coverage of the event. This introduction was then enriched by detailed readings which relied heavily on as much witness and perpetrator testimony as possible. We then studied the Herrero-Nama Genocide (1904-1907), the Holocaust, the Cambodian Genocide, and Rwanda: Herrero/Nama Genocide (Olusoga \& Erichsen, 2010), Holocaust (Borowski, 1967; Browning, 1992; Levi, 1993), Cambodia (Ung, 2000), and Rwanda (Clark, 2010; Gourevitch, 1998; Hatzfeld, 2005). Our historical and geographical examination of genocide closed with students examining various issues regarding prevention, justice, and reconciliation (Heidenrich, 2001; Sewall, Raymond, \& Chin, 2010). By carefully choosing a few examples as well as thematic material, I hoped to avoid a common problem with comparative genocide courses, namely that "we usually try to teach too much...We are addicted to coverage" (Parsons \& Totten, 1991, p. 86). Naturally, some may feel pressures to include certain genocides, but ultimately at the university level the decision rests with the professor. In our course, with a detailed but hopefully manageable understanding of the history of genocide in various contexts as well as the complexities of prevention and response in the modern era, we began the capstone project for the course: the Genocide Prevention Exercise or GENPREVEX.

\section{Walking in a Pedagogical Minefield: The roots of the GENPREVEX}

"Any simulacrum [of the Holocaust] would be unspeakably vulgar." - Thomas Laqueur (Schweber, 2004, p. 60)

\footnotetext{
${ }^{6}$ Graduate students also read (Stone, 2010). Other mandatory reading was Olusoga \& Erichsen (2010), Stearns (2011), Stone (2010) and Ung (2000).
} 
How do we introduce students the complicated mission of identifying, preventing, and responding to genocide in the present? This task is difficult for a variety of reasons. First, finding a "potential" genocide to study in the context of prevention can be difficult as one is often forced to prove a negative. That is, one must find a place where a genocide did not occur or was prevented which can be a difficult endeavor. Secondly, finding source material beyond journalistic sources that deals with the complex interplay of domestic politics, international strategy, issues of sovereignty, NGOs and corporate activity, and national security interests can be overwhelming for students. Lastly, textbook and secondary material (while important) usually speaks in generalities that are easy for students to simply agree with but which do not often challenge them to imagine their implementation on the ground.

In order to address some of these issues, my approach was to create a simulation where students would take on the roles of the myriad of actors in genocide prevention and response. In choosing to run a simulation, I knowingly entered into a pedagogical region of virulent debate. The central issue stems-as many in genocide education do-from Holocaust education. It is not at all uncommon for educators (most often at the secondary school level) to attempt to impart some form of knowledge about the Holocaust through some experiential activity. Almost without fail, these events are so deeply problematic that we might question why anyone would attempt them. Yet teachers continue to do so. One method is an attempt to encourage "identification" through literature. P.R. Bos argues that this approach assumes "that it teaches 'empathy, compassion, and history' in students, and makes them better witnesses to the event" (Bos, 2014, p. 413).

Interestingly, he goes on to note that "in European schools, even in the education of 14-18-year-olds, identification with the victims is not the goal. It would have seemed improper to us, for both non-Jews and Jewish children of survivors alike, to presume that we knew what this kind of suffering was like, or to compare our own experiences to theirs." (Bos, 2014, p. 413).

An even more problematic option is when teachers turn to simulations. These "simulations" often involve segregation, embarrassment, and menial labor as a way of teaching the marginalization that Jews felt. In one such exercise in South Carolina, students played Jews one day and Germans the next. The teacher leading this exercise then made a cringe-worthy observation: "The students in the first group were pretty downtrodden,' she said. 'Then their talk changed. It's very interesting to see how quickly they switch roles. I've had several say, I'm so glad I'm German today'"(Phillips, 2011). In another Holocaust simulation, students were made into victims complete with numbers inked on their arms. One participant summed up this destructive pedagogy aptly, saying: "It's kind of irri- tating, but it's only one day" (Fittes, 2015). As Samuel Totten unequivocally notes, "the best advice in regard to simulations intended to provide students with a sense of Holocaust history, including what the victims lived through and/or the choices that both perpetrators and victims made, is to avoid them [emphasis minel" (Totten, 2001b, p. 251). There is also the issue of honoring and respecting the experience of victims and survivors. For example, could we really simulate the experience of the gas chamber? Of course not. That space, above any in the Holocaust, is one with no witnesses, no survivors. It is truly an unknowable space. Moreover, the danger that any student would walk away from such a simulation believing that they "knew what it was like" is a most disconcerting thought. Ill-conceived simulations are not confined to the Holocaust either. In 2006, mtvU and the Reebok Human Rights Foundation facilitated the creation of a game called "Darfur is Dying" in which users choose to play a member of a Darfurian family during the genocide in Sudan (http://www.darfurisdying.com). The designers note that the game "provides a window into the experience of the 2.5 million refugees in the Darfur region of Sudan." (Ruiz, York, Stein, Keating, \& Santiago, 2006). The surrounding educational material and ways that one can take action are excellent, but the game itself is simplistic and unhelpful in generating an understanding of the conflict. It is important to note that most mainstream Holocaust and Genocide museums and educational institutions do not support pedagogies that are experiential simulations. (USHMM's site "Guidelines for Teaching about the Holocaust", http://www.ushmm.org/educators/teaching-aboutthe-holocaust/general-teaching-guidelines; Bos, 2014) Regardless, this is a continuing problem in some areas, particularly secondary schools.

So why consider a simulation or exercise at all? I felt that in order to help my students understand the most difficult topics of the course-genocide early warning, prevention, and response-the best approach would be for them to experience for themselves the complexities of decisions and the variety of actors and perspectives involved. ${ }^{7}$ The addition of such a project adds an explicit focus on activism and respect for human rights that often remains tangential when conducting an historical survey of genocides. As Betty Reardon, founder of the Peace Education Center at Columbia notes "neither education for action nor education for reflective contemplation characterizes courses in peace studies or peace education. Rather, the learning objectives are still too often built upon traditional educational goals of subject matter mastery" (Reardon, 2013, p. 5). A well-conceived simulation can take students into a world where they can make their own de-

${ }^{7}$ Simulations are de rigeur in a variety of other disciplines such as political science when dealing with other subject matter. 
cisions and get a glimpse of the complexity of interactions between actors. However, Professor James Brown proceeds cautiously, pointing out that, "gamelike simulations may aid the process of dialogue and subsequent critical consciousness that leads to action. But even the best simulations require great care, lest they become mere entertainment" (Brown, 2007). The director of the Stanford History Education Group, Sam Wineburg, insightfully notes "all endeavors in history education inevitably encounter the tension between the knowable and the unknowable as it is woven into the very fabric of the discipline" (Schweber, 2004, p. 62). A properly designed and thoughtful simulation has the potential to bring the unknowable to students in a way that reading and discussing texts alone cannot.

For all these reasons, I decided to have my students work their way through a genocide simulation. However, I also recognized that the ethical problems of simulating an historical genocide (like the Holocaust) made a choice of reenacting history simply impossible and, to me, unpalatable. The obvious workaround seemed to be to build the exercise around a genocide that had not occurred but could occur in the present context. In searching for a setting that met these requirements, I decided upon the Democratic Republic of Congo, particularly the eastern Kivu provinces, an area which has a history of genocide and mass atrocity and constantly ranks high as the site for a potential genocide by the standards of NGOs such as Genocide Watch. Its experience with genocide is current enough for there to be a good deal of information on both the history and the actors, many of whom are still in power. In addition, having spent time in the DRC, I bring a personal connection and perspective to the topic. Lastly, students had read Dancing in the Glory of Monsters by Jason Stearns prior to beginning the simulation. There is no reason that instructors could not choose a different hot spot for their exercise. In any case, by choosing a believable but fictional genocide, I opted to give students more room for charting their own courses while avoiding any attempt to simulate the "experience" of genocide. Students would play the roles of actors and make decisions, but they would not engage in experiential forms of simulation as those mentioned above. They would also, admittedly, not focus on the victim experience.

The design for the GENPREVEX was inspired by several other pedagogical simulations. A major influence was the "Reacting to the Past curriculum" developed at Barnard College. The RTTP teaching format

consists of elaborate games, set in the past, in which students are assigned roles informed by classic texts in the history of ideas. Class sessions are run entirely by students; instructors advise and guide students and grade their oral and written work. It seeks to draw students into the past, promote engagement with big ideas, and improve in- tellectual and academic skills. ("Reacting to the Past," 2014)

RTTP "games" ask students to play roles in historical events from "The Threshold of Democracy: Athens in 403 B.C." to "The Trial of Anne Hutchinson: Liberty, Law, and Intolerance in Puritan New England." Each published game includes a "game book" which delineates the historical context and rules of the game, an instructor manual, and a series of companion texts and primary source readings. There are no Holocaust games and only one genocide-related game, "The Needs of Others: Human Rights, International Organizations and Intervention in Rwanda, 1994", which is in development. ${ }^{8}$ The games provided by RTTP touch on very important aspects of history throughout time and place but few of them treat such difficult and emotionally fraught topics as genocide or mass atrocity. ${ }^{9}$ Thus, for the reasons already mentioned, I had departed immediately from the RTTP model by choosing a fictional event that had yet to happen. This meant that the exercise was openended and not constrained by a history that had already happened. Though I maintained the use of "victory conditions," they served more as guidelines than as strict tools for assessment of success or failure. Regardless, the model of the RTTP was immensely helpful, particularly in creating the necessary course materials.

RTTP is not the only organization that has relied on similar exercises. Former Secretary of State Madeleine Albright uses an intensive simulation when teaching future public policy students. In a 2012 interview, she noted "I have found it helpful for my students to participate in crisis simulation exercises, where each is allowed to play a role" (Kanani, 2012). COL (ret) Dwight Raymond, a co-author of the U.S. military's handbook on Mass Atrocity Prevention and Response Operations, helps run genocide simulations like the one held at Stanford University in 2015. This simulation required participants to "work within an interagency framework to formulate U.S. government policy options to mitigate mass atrocities in Syria, drawing on the range of tools available to policymakers, including sanctions, accountability mechanisms, humanitarian assistance, strategic messaging, and armed force" (MAPRO, 2015). In 2012, representatives from fifteen government agencies had taken part in a similar table-top exercise which was termed an "action conference, not a discussion conference" aimed at helping leaders execute actions on the ground in a related military exercise. A facilitator reported that "[the exercise] replicates what happens in the real world and provides the most realis-

\footnotetext{
8 I would like to thank the author, Kelly McFall, for sharing his insights and his work on this particular game with me.

${ }^{9}$ This is, of course, not to minimize the importance of the topics covered but simply to note that the issues covered tend to be more historicized and distant than the Holocaust and genocide.
} 
tic training environment for our training audiences" (Hernandez, 2012). Thus, I sought to draw on a variety of precedents in creating a useful simulation of genocide prevention and response. ${ }^{10}$

\section{Genocide Simulation in the Classroom}

At the beginning of the Fall semester in 2014, I assigned students their roles for the GENPREVEX. The roles were dependent on the number of students. The roles in play during this simulation are listed below:

President of the United States (Barack Obama) Secretary General of the United Nations (Ban Ki Moon)

President of Rwanda (Paul Kagame)

President of Uganda (Yoweri Museveni)

President of China (Xi Jinping)

MONUSCO Commander (LTG Carlos Alberto dos

Santos Cruz

Oil and Mineral Corporation (a fictional

company, AU79)

Human Rights Watch

International Committee of the Red Cross (Peter

Maurer)

Journalist \#1-Mainstream Media (i.e. CNN, Fox, etc)

Independent/Freelance Journalist

Rebel Leader (Raia Mutomboki Group-

Génocidaire, Gen. Nkende, a fictional

character)

I debated between choosing the roles for the students or allowing them to choose. Ultimately, I decided to choose for them. This allowed me to both play on the strengths of individual students and to place others outside of their comfort zones. For example, I had two veterans in the class; one was given the role of the Secretary General of the U.N. rather than the military commander of UN forces to place him in a diplomatic rather than military position. Conversely, the second student, a graduate student, was given the role of génocidaire as the leader of a rebel group in Eastern DRC. This played to both his experience in the military and also his maturity which was crucial to this role. Student feedback seems to support this choice. One student noted that he "had little if any knowledge about International Corporations and the role they played going in." He went on to become a very adept player. Other students preferred being assigned roles because, naturally, some roles were more ethically suspect than others, particularly that of the perpetrators. One student

10 The United States Institute of Peace runs a series of simulations for policymakers, many of which focus on response to atrocities, both real and fictional. For a list of some of these, see http://www.usip.org/simulations noted assigned roles "relieved the class of any misgivings about playing a morally reprehensible person or faction [and] relieved anyone from asking to play the génocidaire or classmates believing someone wanted to play this role." This is an important insight and should not be misread as removing the moral/ethical component from play but, rather, allowing the students to play their roles as honestly as possible without worrying that they were being judged by their classmates.

Assigning roles at the outset of the class gave the students twelve weeks to research the historical context and behavior of their role in the Great Lakes region of Africa before the exercise began. Several assignments over this twelve-week period helped ensure that each student was fully prepared to participate in the GENPREVEX. First, all students read Dancing in the Glory of Monsters: The Collapse of the Congo and the Great War of Africa by Jason Stearns, a book which lays out the complexities and roots of violence in the modern Democratic Republic of Congo. Secondly, students were required to read and report on media, journal articles, and one book related to their role and its historical context. Thirdly, prior to the beginning of the exercise, each student was required to craft a preliminary strategy. Finally, at the end of each week of the exercise, each student wrote a summary and reaction from the perspective of their role. All of these products and more went into the cumulative creation of a portfolio to be turned in at the end of the semester. In this way, students remained connected to their roles in a present, fictional genocide while studying the details of multiple past genocides. As one student reflected, "Course readings were very important for understanding the context and history of the roles played by all of the students in our simulation."

Each role contained a brief background to the individual or organization as well as a series of victory and defeat conditions meant to help guide the behavior of the player. It was, however, made clear to students that their grades were not dependent on winning or losing but on how accurately and honestly they played their role. Below is one example of an assigned role and its description:

\section{International Corporation}

You are a major multi-national corporation specializing in electronics, especially mobile electronics. As such, the minerals you need that are available in eastern DRC are vital to your business. And if you can get them more cheaply than your competitors, so much the better. You have one allegiance first and foremost: to your shareholders. Your mission is to increase the value of your company so that they (and you) make money. If this means that you engage in some...questionable...business practices you are willing to consider it.

On the other hand, you are certainly aware of the 
possibilities of a public relations disaster if some of your "partnerships" become public. You seek to protect yourself by working through middlemen on the ground to supply you with the materials you need, even if this means dealing with rebel groups that are committing atrocities. You don't see yourself as responsible for criminal activity as you are simply buying minerals...for the moment.

\section{Victory Conditions}

You may win if at the end of the game:

- You have established strong relationships with mineral suppliers in the region.

- You have increased the value of your company (GM discretion)

- The conflict is ongoing such that your bottom line benefits

You may lose if at the end of the game:

- Your sketchy relationships in DRC are revealed by the press

- The violence is successfully ended or reduced

- The rebels are defeated

\section{Suggestions and Guidance}

You need those minerals and eastern DRC is the best place to get them for cheap, giving you an edge on your competitors that translates to dollars back home and makes your yacht payments. You should do everything you can from this perspective to make sure that protect these dealings.

\section{Powers and Responsibilities}

You have money. Lots of it. How you spend it is up to you. You may consult with the GM about the many ways you can employ this resource. Some are more savory than others, but each can have its own results that may be useful to your ends. You are not completely immoral (more like amoral). You see the conflict as separate from your business dealings.

All this preparation resulted in a powerful simulation. I should note that it was intended that a genocide at least begin to take place in order that the students have to respond to it. The learning goals regarding the prevention aspect were gained from reflecting on the developing genocide and brainstorming wargaming what could have been done to prevent it. Nothing about the exercise or the course suggests that genocide is inevitable; throughout the course in their assigned readings, students are repeatedly confronted with both historical efforts to prevent genocide and the current theories of R2P and genocide prevention.

In 2014, the fictional Congolese mass atrocity of 2014 began with ethnic tensions in the eastern province of North Kivu, led by a mysterious rebel leader of a Raia Mutomboki group. This group's leader fought un- der the pseudonym "The Uncle". ${ }^{11}$ He sought to unite various groups of local militia to attack Hutus who he associated with FDLR (Forces dèmocratique de liberation du Rwanda) from Rwanda that had committed atrocities against Congolese Tutsis. "The Uncle" laid out his plan in his initial game plan in part by writing "my first step will be to negotiate with fellow Raia groups, offer assistance to the Tembo and Kifuafua ethnic groups that look toward my faction for protection, and finally to secure an operative deal with corporate and/or Chinese representatives in order to begin the flow of resource trade." He was, in fact, successful enough to gain DRC President Joseph Kabila's support and emerge as General Nkende. Very shortly, however, things began to spiral out of control. The Uncle's actions, masked by his concerns for security, quickly led to the targeting and murder of Hutu civilians. This, in turn, led to a burgeoning humanitarian crisis as thousands of refugees and survivors flooded the roads in search of safety in the larger towns of the region. The Red Cross recognized the danger and began to develop a plan to assist these refugees, but found itself stymied frequently by a variety of complications. Human Rights Watch as well began clamoring for action but found little interest in the real power brokers. These frustrations were borne out by the students playing these NGOs. One remarked that "as an NGO, you have no idea what to do or where to do it, and you're frantically trying to meet with leaders that couldn't care less about you."

Meanwhile, negotiations were taking place behind the scenes between the Uncle and President Kabila. In return for legitimacy, the Uncle, now in the open as General Nkende, pledged to support Kabila's policies in the region (while Kabila helpfully looked away from the militia's human rights abuses). It is important to note here that the GENPREVEX format allows actors to shift in their roles during the course of the exercise. They can begin as victims and become génocidaires. In addition, they can move from rebel to an instrument of the government as Nkende does. The UN was slow to act, attempting to build a consensus with Uganda Rwanda, and the DRC before moving on these rebel groups. Naturally, this allowed the militia to commit more atrocities and to gain more support. Moreover, Uganda and Rwanda's interests historically have been to increase their own control in the region and so they were less interested in how to prevent violence than how to turn it to their advantage (Prunier, 2009). The students playing these roles did a superb job of aggressively pursuing their own goals in the region. As the Red Cross struggled to set up camps for refugees, our fictional

11 The Raia Mutomboki are a group of paramilitary militias operating in the North Kivu province of DRC. For more, see (Stearns, 2013). This and other information about the DRC is available online at http://www.riftvalley.net/publication/raiamutomboki 
corporation, AU79, sought to make deals with a variety of actors to secure its mineral interests in the region. This eventually led it into an agreement with various rebel groups in exchange for their operation and safeguarding of mineral extraction as well as to China's more distant involvement in this process. Frequently, we would use maps that partially depicted the current situation on the ground. These maps would be updated before each class meeting (see Figure 1).

Our student journalists struggled to sort out the truth on the ground and were required to publish several articles each week which one did with the aid of a fantastic online application they discovered: Newsjack (see Figure 2; http://newsjack.in). Our mainstream reporter, working for CNN, published via the fictionalized Newsjack website while our freelance/independent journalist, who was on the ground, published via a blog, DRC Daily (http://drcdaily.blogspot.com).

Student journalists actually conducted interviews with various actors in character inside and outside of class, sometimes even scoring exclusive interviews. In addition, their efforts affected the other players. As one participant noted, "everyone was much more involved than I thought, and everyone stayed in character even outside of the classroom. It was intricate and often I would call up classmates with frantic concerns after an e-mail was blasted out or a story was leaked."

Given the amount of contact outside of class and the fictional nature of the simulation, which allowed for many contingencies, I, as the facilitator, at times was called upon to act in a "God" role or to play roles which lacked students or became necessary. I would also selectively leak information to various parties based on what they could be expected to know to help spur action and move the simulation along. One of the more interesting of these roles was as the "Panther of Kalehe." The Panther was a local militia leader initially allied with General Nkende. However, he eventually chafed at the normalization of relations with Kabila which failed to benefit him and began escalating violence on his own, in defiance of Nkende's attempts to control him. When his troops shot down a UN helicopter with missiles supplied by China in an attempt to undermine the general's legitimacy in the region, the situation escalated even further. MONUSCO, the UN armed force in the region was slow to act, not least given the military weakness of troops supplied by member nations which accurately reflected the reality on the ground. As the semester (and the simulation) ended, MONUSCO was preparing a major offensive against the Panther but was hamstrung in dealing with Nkende due to his close ties with Kinshasa. The United States was providing intelligence and considering limited Special Forces action in support of MONUSCO. During and after the simulation, students reflected on the issue of prevention as well. One of the most common suggestions by students for improvement was that the simulation be allotted more time than four weeks to allow them to develop their actions even more deeply.

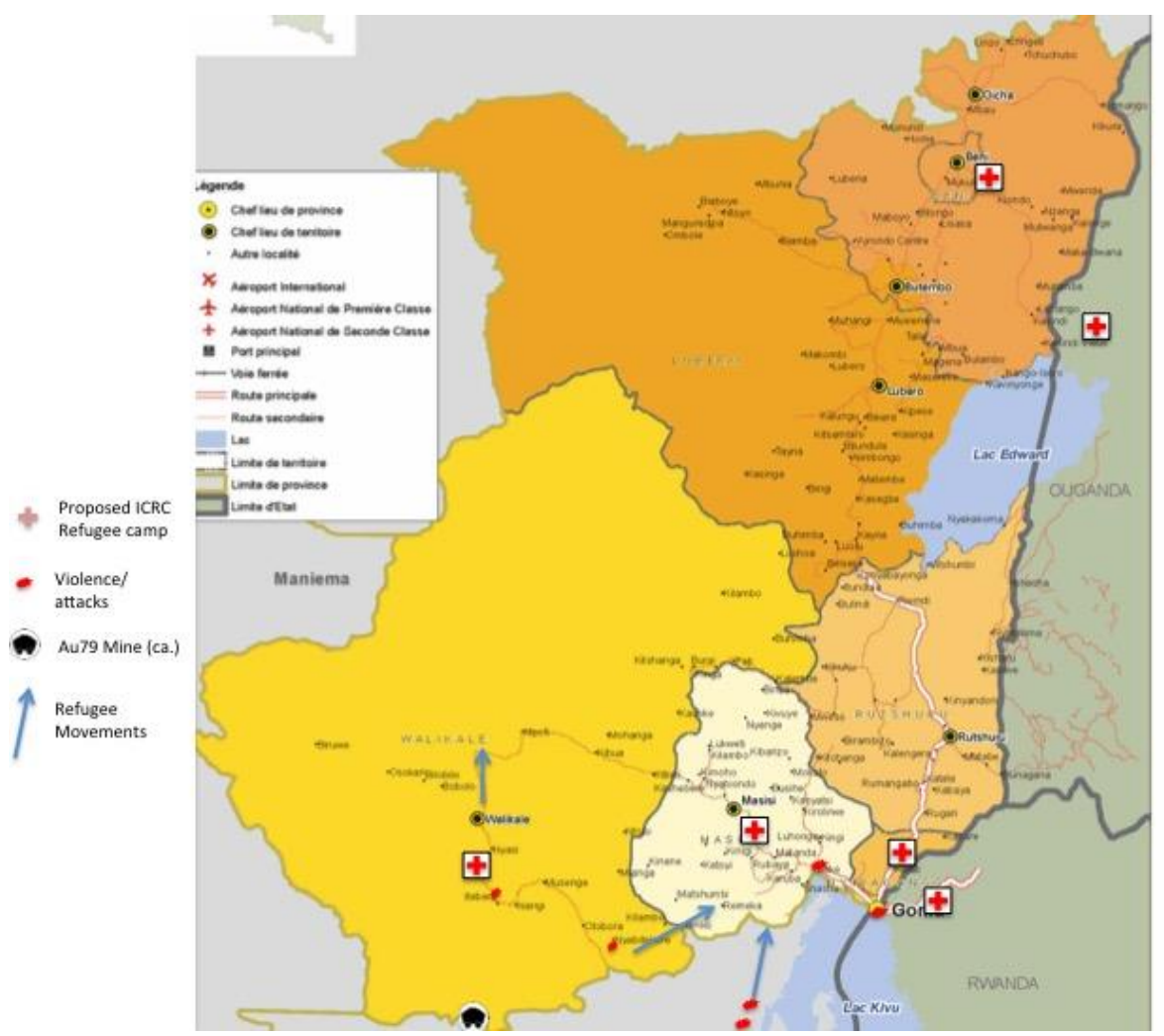

Figure 1. Map depicting attacks on civilians, movement of refugees, gold mines, and locations of proposed Red Cross refugee camps. 


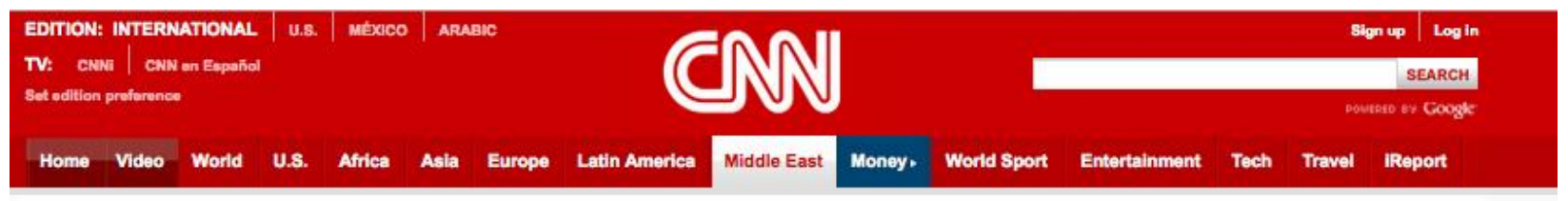

\section{Thousands of innocent lives taken in the DRC death tolls quickly rising}

By Sharon Gladstone, CNN

December 6, 2014 - Updated 2251 GMT (0651 HKT).

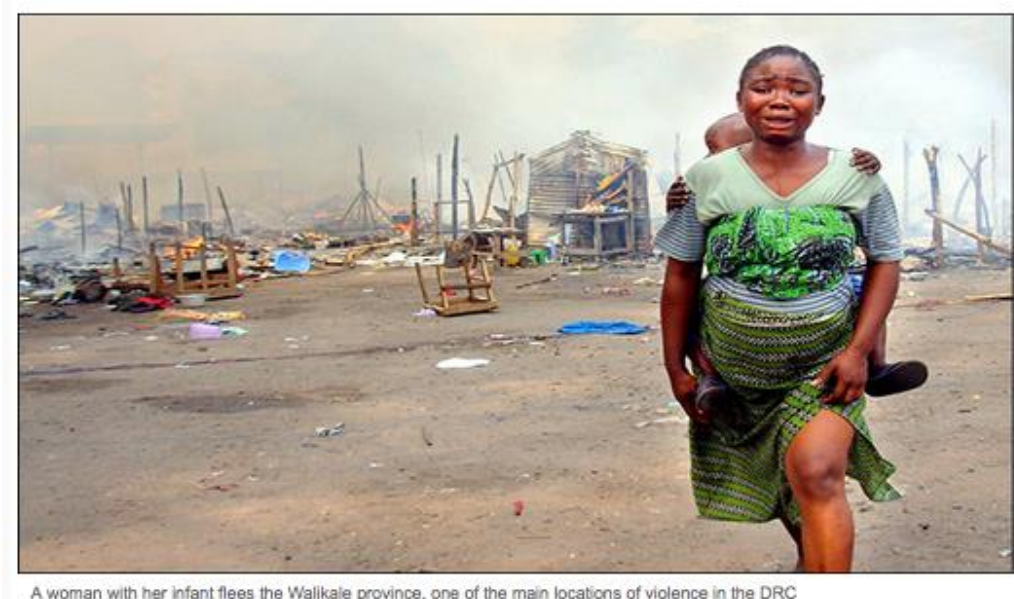

\section{STORY HIGHLIGHTS}

- AID organization posted video from his wife prior to his death

- Yolande Korkie said her husband was a "respected teacher

- South African media reported the couple had worked in Yemen for four years

- They were kidnapped in 2013 she was freed in January

\begin{abstract}
(CNN) --Bridge explosions, hostage situations, violent attacks on innocent women and children, this is just a brief recap of the terror that has ripped through the Congo in only three weeks time.

One source has reported that since the violence began, there have been 10,000 deaths in both Kivu provinces alone.

As if these atrocities weren't enough within themselves, thousands of people in the DRC are being forced to flee their homes. To escape the violence, these refugees have been displaced. The ICRC is overwhelmed trying to provide aid.
\end{abstract}

SHARE THIS

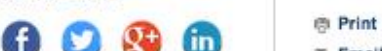

$\approx$ Email

I More sharing

\section{Most Popular 》 \\ Today's five most popular stories}

Glitter, glam and nudity: Behind the scenes at the legendary Studio 54

Faster than a speeding bullet? Meet the world's first $1,000 \mathrm{mph}$ car

11 of the world's top city golf clubs

A year after Haiyan's devastation, new typhoon threatens Philippines

New 'Terminator: Genisys' trailer explodes online More

Figure 2. One of the first news articles out of the simulation.

\section{Conclusions and Outcomes}

"The students played to the self interests of their factions well enough to reveal the machinations that enable genocide in ways I did not expect." Student feedback, 2014.

Overall, this simulation demonstrated what I found to be one successful approach to bringing the complexities of genocide to life for students in a way that was neither simplistic nor disrespectful to the memory of historical atrocities. At the beginning, I was admittedly concerned about the possibility of simulation becoming more about winning and "fun" than about learning. Yet, I was pleased to find that this was not the case. While students reported being excited about taking part in the simulation and while there were certainly moments of levity, on the whole, participants became very careful stewards of their roles. As one remarked, "students took their roles seriously and showed a great deal more motivation than I would have hoped for." In addition, as the facilitator, I was able to call "timeouts" and to step in at times to highlight key phenomena that were occurring. I was also able to be a resource for individual players to access when considering their next move or when they needed the position of a role or actor not present in the simulation to be played. Students were able to reach levels of complexity that were often incredible. Our investigative reporter published a story on forced prostitution in the corporation's mining camps and was then threatened with deportation by the Congolese government. The Secretary General of the UN called for several summits which often devolved into bluster by all sides; much more seemed to be accomplished behind the scenes via bilateral agreements and even then, the UN found itself often unclear on who to trust. As a result, Ban Ki Moon and President Obama directly confronted one of the major complexities of genocide prevention and response, in this case, sanctions: 
"Knowing that the UN and America were the big contributors, we discussed pulling funding. The problem is that would've hurt the DRC President but moreover it would've been detrimental to the people. Many decisions fell into a similar predicament; one action, against or for, the leader has 10 times the effect on the population. Sometimes we think of the simple fix which could be easier to accomplish and it would take less money and less resources. When actually sitting in the position to make that call, it changes things."

Students appear to have really been able to grasp some of the key issues surrounding intervention in genocide on the ground. As one noted, "I don't think it is a stretch to believe that students understood the 'mental gymnastics' groups and individuals go through as they decide to ignore or support a perpetrator of genocide, but they likely got a better view of these an other forces in action."

What were the lasting outcomes of this exercise? First, students improved their academic research and critical thinking skills. I would echo my colleague's observation from her RTTP experience that for some students "especially those who have learned how to navigate the [traditional academic] system and find themselves at ease in the traditional lecture-reviewtest schema, role-immersion games can be perceived as a destabilizing step out of their comfort zone, requiring the mastery of skills that go beyond good comprehension of the text, attentive note-taking and retention of key information" (Saltamacchia, 2015, p. 7). One participant in the simulation noted that "it forced you to research in a way that you normally wouldn't." Students needed to deal with scholarly material, historical contexts, recent journalistic media accounts, as well as the fictional material generated by their classmates and this challenged them in a way that a more standard presentation might not.

Secondly, students seemed to gain a greater appreciation for the complexities of mass atrocity prevention and response when it was taken out of a textbook and placed before them in "realtime." This simulation became very real and stressful as one participant remarked. "For example: when the [Uncle who] was allegedly committing genocide was given a high ranking position in the army and had legitimate power, I had to deal with dozens of phone calls from frantic individuals trying to conduct damage control." Bear in mind, these are real phone calls from other players outside of class. For some students, the simulation opened them to further investigation of genocide on their own. Our corporate executive reported that "I had little if any knowledge about International Corporations and the role they played going in. Now I am actively looking at conflict mining and how it plays a role in genocides." Another reflected that, "I learned a lot, think about this stuff all the time [emphasis student] while listening to the news." Finally, in summing up, one participant explained that "even as information kept coming out about the actions of corporations and rebel groups as well as the surrounding countries it really showed the complexities as well as reluctance of the international community to act. Lack of response even in a controlled setting was very powerful."

Student feedback and learning outcomes from the course suggests that many became more aware of the importance of taking action to prevent genocide and the many actors involved. The GENPREVEX appears to have addressed one of the key goals of U.S. education as articulated by the United States Holocaust Memorial Museum, "to examine what it means to be a responsible citizen" (USHMM "Why Teach About the Holocaust?", http://www.ushmm.org/educators/teachingabout-the-holocaust/why-teach-about-the-holocaust).

What does this discussion tell us about the utility of simulations in both teaching about genocide and in inspiring students to become responsible stewards of human rights in a global context? First, it shows that we can conduct a simulation without venturing into dangerous ethical waters and by minimizing the danger of oversimplifying an historical event. By NOT choosing an actual genocide, such as the Holocaust, we instantly avoid the danger of attempting to recreate an experience that we cannot possibly feel or understand in the ways that its victims did. Secondly, it shows that we can and must place the simulation in the historical context of comparative genocide with the recognition that all genocides have elements in common; without this recognition, our students and future policymakers will lack the ability to recognize these recurring warning signs in modern genocides. As Joyce Apsel reminds us, "by studying the similarities and differences of processes and patterns of destruction, students gain a deeper understanding of how elites compute a calculus of genocide and decide that eliminating certain groups is a politically effective policy. Emphasizing the "rationality" of genocide is crucial." (Apsel, 2004, pp. 117118). This exercise appears to have been successful in doing this for its participants.

Perhaps I should close with some thoughts on the future of simulations in teaching about genocide. I reiterate the critiques and general condemnation of attempting to create experiential simulations of past genocides aimed at getting students to "get" what it was like. However, I suggest that simulations like the GENPREVEX allow us to sidestep this danger by focusing on the modern complexities faced by decisionmakers in a world of gray, where clear distinctions between right and wrong are few and where they are free to attempt their own actions without the constraints of what actually happened. None of this is possible, of course, without the significant historical background of past genocides gained in the first part of the 
course. A simulation such as this can be scaled up to include more actors and with a knowledgeable instructor facilitating can be guided to highlight a myriad of different issues. Lastly, it seems that exercises such as these do motivate students to be more aware of the world around them, the potentials for genocide globally, and the decidedly complicated factors affecting our response.

\section{Acknowledgments}

I would like to thank first and foremost my students at the University of Nebraska-Omaha without whom, this simulation would not be possible and who went above and beyond in making the exercise work. They also challenged me to reflect upon and improve it. I would also like to thank Kelly McFall who designed the Rwanda exercise for Reacting To The Past and whose advice was invaluable. In addition, I am thankful for my colleagues at the University of Nebraska-Omaha who shared their advice and experience with me. Lastly, I would like to thank the anonymous reviewers whose commands and suggestions were very helpful in polishing this article and for the editors. All errors remaining are the mine alone.

\section{Conflict of Interests}

The author declares no conflict of interests.

\section{References}

Apsel, J. (2004). Moral dilemmas and pedagogical challenges in teaching about genocide. Human Rights Review, 5(4), 104-129.

Bartrop, P. R. (2012). A biographical encyclopedia of contemporary genocide. Santa Barbara: ABC-CLIO.

Borowski, T. (1967). This way for the gas, ladies and gentlemen; and other stories. New York: Viking Press.

Bos, P. R. (2014). Empathy, sympathy, simulation? Resisting a holocaust pedagogy of identification. The Review of Education, Pedagogy, and Cultural Studies, 36, 403-421.

Brown, J. G. (2007). Teaching about genocide in a new millennium. Social Education, 71.

Browning, C. R. (1992). Ordinary men: Reserve Police Battalion 101 and the final solution in Poland (1st ed.). New York: HarperCollins.

Clark, P. (2010). The Gacaca courts, post-genocide justice and reconciliation in Rwanda: Justice without lawyers. Cambridge: Cambridge University Press.

Fittes, E. K. (2015). Holocaust simulation teaches tolerance. The Star Press. Retrieved from http://www.thestarpress.com/story/news/educatio n/2015/04/16/holocaust-simulation-teachestolerance/25892179
Gladstone, S. (2014). Thousands of innocent lives taken in the DRC death tolls quickly rising. CNN. Retrieved from http://nsjk.in/5484bb0c69cb9

Gourevitch, P. (1998). We wish to inform you that tomorrow we will be killed with our families: Stories from Rwanda. New York: Farrar, Straus, and Giroux.

Hatzfeld, J. (2005). Machete season. The killers in Rwanda speak: A report. New York: Farrar, Straus and Giroux.

Heidenrich, J. G. (2001). How to prevent genocide: $A$ guide for policymakers, scholars, and the concerned citizen. Westport: Praeger.

Hernandez, C. E. C. (2012). MCTP hosts mass atrocity prevention, response exercise. Retrieved from http://www.army.mil/article/82891/MCTP_hosts_ mass_atrocity_prevention_response_exercise

Hilsum, G. (2014). The UN reacts to the Helicopter Crash in Walikale. Retrieved from http://drcdaily.blogspot.com

Kanani, R. (2012). Former Secretary of State Albright: "What would we have done?". Forbes. Retrieved from

http://www.forbes.com/sites/rahimkanani/2012/0

5/10/former-secretary-of-state-albright-whatwould-we-have-done

Levi, P. (1993). Survival in Auschwitz: The Nazi assault on humanity. New York: Collier Books.

Lindsay, B. C. (2012). Murder state: California's native American genocide, 1846-1873. Lincoln: University of Nebraska Press.

Mass Atrocities Prevention and Response (MAPRO) Tabletop Simulation (2015). Retrieved from https://www.law.stanford.edu/event/2015/02/13/ mass-atrocities-prevention-and-response-maprotabletop-simulation

Milgram, S. (1969). Obedience [videocassette]. University Park, PA: Pennsylvania State University.

Olusoga, D., \& Erichsen, C. W. (2010). The Kaiser's holocaust: Germany's forgotten genocide and the colonial roots of Nazism. London: Faber and Faber.

Parsons, W. S., \& Totten, S. (1991). Teaching and learning about genocide: Questions of content, rationale, and methodology. Social Education, 55(2), 84-90.

Phillips, N. (2011, 30 January). Prejudice simulation adopted, cautiously, as a teaching tool. Washington Post.

Prunier, G. (2009). Africa's world war: Congo, the Rwandan genocide, and the making of a continental catastrophe. Oxford and New York: Oxford University Press.

Reacting to the Past. (2014). Retrieved from https://reacting.barnard.edu

Reardon, B. A. (2013). Meditating on the barricades: Concerns, cautions, and possibilities for peace education for political efficacy. In P. P. Trifonas \& B. L. Wright (Eds.), Critical peace education: Difficult 
dialogues (pp. 1-28). London: Springer.

Ruiz, S., York, A., Stein, M., Keating, N., \& Santiago, K. (2006). Darfur is dying. Retrieved from http://www.darfurisdying.com/aboutgame.html

Saltamacchia, M. (2015). Teaching the crusades with role-playing simulations: Reacting to the past's "The Second Crusade: The War Council at Acre, 1148". In International Symposium on Crusade Studies 2014 proceedings. Farnham: Ashgate.

Schabas, W. A. (2009). Genocide in international law the crime of crimes. Leiden: Cambridge University Press.

Schweber, S. (2004). Making sense of the Holocaust: lessons from classroom practice. New York: Teachers College Press.

Sewall, S., Raymond, D., \& Chin, S. (2010). MARO: Mass Atrocity Response Operations: A military planning handbook. Cambridge, MA: Carr Center for Human Rights Policy, Harvard Kennedy School and US Army Peacekeeping and Stability Operations Institute.

Staub, E. (1989). The roots of evil: The origins of genocide and other group violence. Cambridge and New York: Cambridge University Press.

Stearns, J. K. (2011). Dancing in the glory of monsters: The collapse of the Congo and the great war of Africa. New York: PublicAffairs.
Stearns, J. K. (2013). Raia Mutomboki: The flawed peace process in the DRC and the birth of an armed franchise. London: Rift Valley Institute.

Stone, D. (Ed.) (2010). The historiography of genocide. New York: Palgrave Macmillan.

Totten, S. (2001a). Addressing the "null curriculum:" Teaching about genocides other than the holocaust. Social Education, 65(5). Retrieved from http://go.galegroup.com/ps/i.do?id=GALE\%7CA789 $16697 \& v=2.1 \& u=d u k e \_p e r k i n s \& i t=r \& p=A O N E \& s w=$ w\&asid=60b5aa91bb667d864dc962579b2253b9

Totten, S. (2001b). Diminishing the complexity and horror of the holocaust: Using simulations in an attempt to convey historical experiences. In S. Totten (Ed.), Teaching holocaust literature (pp. 243251). Boston: Allyn and Bacon.

Ung, L. (2000). First they killed my father: A daughter of Cambodia remembers. New York: Harper Collins Publishers.

Waller, J. (2002). Becoming evil. How ordinary people commit genocide and mass killing. Oxford and New York: Oxford University Press.

Zimbardo, P. G., Musen, K., \& Polito, J. (1992). Quiet rage: The Stanford prison study [videorecording]. Stanford, CA: Stanford Instructional Television Network, Stanford University.

\section{About the Author}

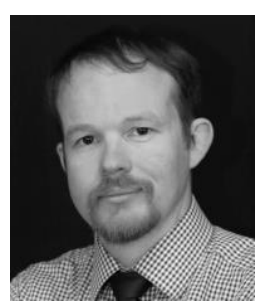

\section{Dr. Waitman Wade Beorn}

Dr. Waitman Wade Beorn is the Director of the Virginia Holocaust Museum in Richmond, VA. He was previously the inaugural Louis and Frances Blumkin Professor of Holocaust and Genocide Studies and assistant professor of History at the University of Nebraska-Omaha. He is the author of Marching Into Darkness: The Wehrmacht and the Holocaust in Belarus (2014). He is currently preparing a major project on the Janowska concentration camp outside of Lviv, Ukraine. 